\title{
A Good Time to Stay Out? Strikes and the Business Cycle
}

Paul J. Devereux

Robert A. Hart

Stirling Economics Discussion Paper 2008-12

July 2008

Online at http://www.economics.stir.ac.uk 


\title{
A Good Time to Stay Out? Strikes and the Business Cycle
}

\author{
by \\ Paul J. Devereux \\ School of Economics and Geary Institute UCD, CEPR and IZA \\ devereux@ucd.ie \\ Robert A. Hart \\ Department of Economics \\ University of Stirling and IZA \\ r.a.hart@stir.ac.uk
}

July 2008

JEL: E32, J31

Keywords: Strikes, Cyclicality, Duration, Incidence, Outcome

\begin{abstract}
In this paper, we compile a unique historical dataset that records strike activity in the British engineering industry from 1920 to 1970 . These data have the advantage of containing a fairly homogenous set of companies and workers, covering a long period with varying labour market conditions, including information that enables the addition of union and company fixed effects, and providing geographical detail that allows a districtlevel analysis that controls for year and seasonal effects. We study the cyclicality of strike durations, strike incidence, and strike outcomes and distinguish between pay and non-pay strikes. Like the previous literature, we find evidence that strikes over pay have countercyclical durations. However, in the post-war period, the magnitude of this effect is much reduced when union and firm fixed effects are included. These findings suggest that it is important when studying strike durations to take account of differences in the composition of companies and unions that are involved in strikes at different points of the business cycle. We also find that strike outcomes tend to be more favourable to unions when the national unemployment rate is lower.

Acknowledgements: Bob Hart acknowledges funding for this project from ESRC Grant RES-000-22-1804. The full strikes data are available at the UK Data Archive, Study Number 5841 (http://www.data-archive.ac.uk/search/searchStart.asp and search for study number). We are grateful to the Engineering Employers Federation for allowing access to their payroll statistics and to Warwick University Modern Record Centre and Glasgow University Archive Centre for their help in assembling the material. This work has greatly benefited from the inputs of Andrew Currall and Daniel Currall who transcribed the data and from Elizabeth Roberts who provided research assistance.
\end{abstract}




\section{Introduction}

Economists have long been interested in how strike duration and strike incidence change with labour market conditions. Evidence from the U.S. (Kennan 1985) and Canada (Harrison and Stewart 1989) suggests that strike durations are countercyclical. The North American evidence lends more qualified support to the view that strike incidence is procyclical (Kennan, 1986; Harrison and Stewart, 1994). However, the findings are by no means uniform across the strikes' literature. In this paper, we use a new data set that we have put together from the strikes records of the Engineering Employers Federation (EEF) in Great Britain. Statistics cover 10,870 company-level strike incidents over the period 1920 to 1970 . These unique data allow us to study strike durations in a relatively homogenous industry and so differ from the cross-industry studies that dominate earlier research work. ${ }^{1}$

Our data add to earlier studies in several other ways. First, they cover a long period that straddles two colossal events, the Great Depression and the Second World War (WW2). As such, there is tremendous variation in cyclical conditions over the sample period. Second, they allow use of other comparable data collected for this period, especially district-level unemployment rates. These rates, matched to districts in which strikes took place, enable us to exploit cross-sectional variation in labour market conditions in addition to time-series variation. Third, we make use of company and union identifiers to investigate the robustness of our estimates to the presence of company and union fixed effects. Including these extra controls increases the likelihood that we are

\footnotetext{
${ }^{1}$ Also, the engineering industry was particularly strike-prone. Durcan et al. (1983) report that $57 \%$ of major stoppages (defined as involving the loss of 5000 working days or more) in all British industry (excluding Mining) between 1946 and 1973 were accounted for by just five industries; these were, in descending order, motor vehicles, non-electrical engineering, electrical engineering, iron and steel, and shipbuilding.
} 
capturing true cyclical effects rather than selection effects. Finally, we add to the literature by examining how labour market conditions impact strike outcomes. In particular we examine whether unions are more likely to obtain successful outcomes if the unemployment rate is low.

\section{Is there a Good Time to Stay Out?}

Would we expect strike activity to link systematically to changes in the macroeconomic climate? The dominant approaches to understanding strikes incidence and duration (see, especially, Kennan 1986) appear to give, at best, equivocal answers.

One view effectively rules out significant correlations between strike incidence/duration and the business cycle. Hicks (1932) holds that strikes occur more or less randomly, resulting from irrational bargaining behaviour. If the company and its workforce are fully and symmetrically informed about internal and external product and labour markets, then they can rationally achieve an optimal contractual relationship without recourse to costly and inefficient disputes and work stoppages.

For strikes to occur under conditions of full rationality requires an assumption of private information, the principal motivation behind the dominant approach to explaining strike activity. In a company-union context, for example, strikes can be seen as a means of one (or both) party's willingness to incur costs in order to elicit more information from the other side of the dispute. Generally, the assumption is that the company has private information about profitability and the union about its members' appetite and capacity for strike action. In screening models, the union makes take-it-or-leave-it wage offers to the company and strikes if an offer is rejected. The company balances the cost of a strike of a 
given expected length followed by settlement at a low wage against the cost of accepting the union's initial high wage offer and not facing a strike. Signalling models have the opposite structure in that the informed party, the company, makes the wage offers. There are also models in the literature that allow for private information on both sides and/or both screening and signalling elements (Kennan and Wilson 1993, Cramton and Tracy 2003). However, it is difficult to envisage product and labour market conditions playing a prominent role in models that stress the motivating role of variables that are asymmetrically understood by the parties. ${ }^{2}$

In the literature, there is limited evidence of procyclical strike incidence and somewhat broader support for countercyclical strike duration. These are plausible outcomes from a union perspective. When sales are high and inventories are low and when productive workers are faced with abundant job opportunities, the company may perceive particularly high costs of work stoppages. This would seem to provide a good time for the union to solve a grievance through strike action since there is pressure on the company to expedite matters. When unemployment is high, the union may perceive high costs to strike action (Farber, 1978). Alternative sources of employment income for strikers (part-time jobs, the black economy) will be relatively scarce and the situation may be exacerbated if wider family members are also experiencing adverse job conditions. Moreover, when strikes do occur during economic downturns, high

\footnotetext{
${ }^{2}$ Booth and Cressy (1990) establish a possible connection between private information regarding company profit and the business cycle. Companies with high capacity utilisation, ceteris paribus, may be perceived to enjoy high profits and so be more strike-prone. This line of reasoning suggests procyclical strike incidence. In their regression analysis, however, the two measures used by these authors to proxy utilisation (rising/stable sales and establishments operating at full capacity) produce contradictory results.
} 
inventories and thin order books may provide conditions in which employers can afford

to be more robust in their resolve, resisting demands for relatively protracted periods. ${ }^{3}$

Kennan (1986) and Cramton and Tracy (2003) argue that it is a challenge for bargaining models to underpin theoretically findings of procyclical incidence and countercyclical duration. But, there is considerable room to be cautious over treating these outcomes as if they represented a consensus among researchers. Strong counter evidence exists. Analysing 6,000 negotiations in British manufacturing in the 1980s, Ingram et al. (1993) find significant countercyclical strike incidence. Based on a U.S. data set covering over 6,000 union contracts for the period 1970 to 1981, McConnell (1990) finds no evidence of cyclical variation in strike duration.

\section{Data and Descriptive Analysis}

The strike records we use come from a set of volumes on engineering strikes within the Engineering Employers' Federation (EEF) ${ }^{4}$ that are stored at the University of Warwick’s Modern Records Centre. These provide company-level annual strike information for all the Federation's members over an unbroken period from 1920 to 1970. The data are very comprehensive: for each strike, they report the name of the company involved, the union(s) involved, the geographical engineering district (e.g.

\footnotetext{
3 There is an obvious counter argument (Vanderkamp, 1970). If product market demand is generally weak then employers may be wary of jeopardising their relationship with existing customers given a relative abundance of alternative supply sources.

4 The Employers' Federation of Engineering Associations was established in 1896 and by 1899 had become known as the Engineering Employers' Federation. It later merged in 1918 with the National Employers' Federation and become known as the Engineering and Allied Employers' National Federation. In 1961 it changed its name back to the Engineering Employers' Federation (EEF). The EEF is the largest sector employers' organisation in the United Kingdom with a current membership of nearly 6000 companies throughout the country.
} 
Coventry), the cause of the strike, the outcome or resolution, the strike duration in days ${ }^{5}$ (with precise start and end dates), the numbers involved (by men, women and boys), the classes of workers involved (e.g. toolroom fitters, machinemen), and numbers of workers incidentally laid off as a result of the strike. The level of detail is consistent for each and every year over the half century covered. We have transcribed these data on to spreadsheets in a systematic fashion so that they are useful for statistical analysis. There are no censored durations because all reported strikes had ended at the end of the data.

By far the highest strike incidence in our data occurred during the 1960s (see Figure $2 \mathrm{~b}$ and Table 3 below). We are able to undertake an especially detailed investigation of this important strikes period as monthly district-level unemployment rates are available for the period 1960-1970 for 54 engineering districts. (Districts are listed in Appendix Table 1). We match these exactly to the start month of the strike and to the EEF district in which each strike occurred.

Because we are using a new dataset, we now describe some of the characteristics of the included strikes and describe how these relate to information in the literature from other sources.

\section{Determinants of Working Days Lost}

The number of working days lost as a result of strikes depends on three factors the number of strikes, the average strike duration, and the average number of workers per strike. Following Forchheimer (1948) and Knowles (1952), Figure 1 shows the annual decomposition of total days lost due to EEF strikes sub-divided into these three factors.

\footnotetext{
${ }^{5}$ For strikes lasting less than a day, durations are reported in hours.
} 
Let DAYSLOST = total working days lost (per-period), STRIKES = number of strikes, MEANDUR = average strike duration, and MEANW = average number of workers involved in strikes; then $\ln ($ DAYSLOST $)=\ln ($ STRIKES $)+\ln ($ MEANDUR $)+$ $\ln ($ MEANW). The latter expression is graphed in Figure 1. It is clear that all three components play an important role in determining the total number of working days lost. Note the large fall in the number of strikes in the mid 1920s to early 1930s. This is not special to our EEF data but is true in general for engineering and related metal industries, as illustrated in Appendix Table 2.

\section{Numbers of Strikes}

Figures $2 \mathrm{a}$ and $2 \mathrm{~b}$ show the annual number of strikes taking place within the EEF from 1920 to 1970. They also show the number of strikes within British Industry as a whole. Clearly, EEF and national patterns match closely. Figure 2a covers the period from 1920 to the end of WW2. The two marked features are (a) the relatively low level of strike activity between 1922 and 1934 and (b) a growth in the number of strikes in the run up to and during WW2. For the first of these sub-periods, Knowles (1952, p.145150) finds little evidence of national level relationships between the number of strikes on the one hand and the cost of living, weekly wage rates and union membership on the other. Low levels of strikes do tend to correspond more closely with high national unemployment rates, but even these associations are not altogether very persuasive. ${ }^{6}$ In the second sub-period, there were large numbers of official and unofficial engineering

\footnotetext{
${ }^{6}$ For example, unemployment rates peaked in 1931 and 1932, at the height of the Great Depression, with about one-quarter of the workforce unemployment on average in EEF engineering districts (Hart and MacKay, 1975). But strike activity was at its lowest in 1927 when, at 10\%, unemployment was well below its peak.
} 
strikes resulting, in particular, from pressures of war demands on the industry. A very noticeable feature of Figure 2b, covering post-war strike numbers, is that strike activity increases considerably during the 1960s. This is in line with other sources that have demonstrated an upsurge in strikes at this time. Galambos and Evans (1977) show that, during the period 1965 - 1970, "the Vehicles, Aircraft, Metal Manufacture and Engineering groups, already isolated as 'strike prone', continue to deteriorate during this period”. Between 1965 and 1970, these authors show that between 20 and 25 percent of all U.K. industrial disputes (excluding Mining) occurred in engineering and electrical goods.

\section{Pay Versus Non-Pay Strikes}

The data include reported reasons for striking and, in common with a number of papers in the literature, we have used these to classify strikes as pay-related or non-payrelated. Respective issues and frequencies are shown in Tables 1a and 1b, in terms of the whole period as well as pre-war and post-war years. ${ }^{7}$ For all three periods in Table 1a, the predominant pay disputes involved wages, bonuses and piece rates. ${ }^{8}$ Non-pay strikes occur for many different reasons, although disputes involving perceived wrongful dismissal and union-related grievances are clearly generally important. ${ }^{9}$

\footnotetext{
${ }^{7}$ The complete data set, published in the UK Data Archive (see Acknowledgements for full reference), contains more detail about the reason behind each strike.

${ }^{8}$ Knowles and Hill (1954) provide an excellent discussion of these payment methods within the context of the EEF payroll data.

${ }^{9}$ Galambos and Evans (1977) show that in Metals and Engineering Industries the two main reasons for non-pay stoppages from 1965 to 1969 were (a) disputes concerning the employment and discharge of workers (between 9 and 22 percent of all stoppages during this period), and (b) other working arrangements, rules and discipline (between 5 and 16 percent). The first of these matches 'wrongful dismissal', the most important cause of non-wage disputes in our data (see Table 1b). The second, almost certainly is included in 'treatment of workers', the third in importance.
} 
Figure 4 plots the proportion of non-pay to total strikes from 1920 to 1970 . To the extent that we can verify, this is quite strongly representative of the reported incidence of non-pay disputes in other sources. For the period 1965 - 1970, Galambos and Evans (1977) report proportions of non-pay strikes of (respectively) 49.7, 44.4, 51.3, 21.0, 37.1 and 27.6 for the Metals and Engineering industries. For the period 1945 - 1957, McCarthy (1977) shows that $54.8 \%$ of all U.K. strikes involved non-pay issues. For all British industry over the entire period 1946 to 1973, Durcan et al. (1983) show that nonpay strikes constituted about $51 \%$ of all strikes.

\section{Strike Duration}

Table 2 presents information on strike durations by pay and non-pay issues. It shows that durations are longer for strikes in which pay is a factor. Also, strikes tend to last longer in northern districts (North of England and Scotland) presumably reflecting greater militancy among workers and their unions in the older, more traditional engineering areas. Durations in general were considerably longer in the pre-war compared to the post-war era. Wartime strike durations were lowest, with much unofficial strike action.

Table 3 shows the mean, median and survival rates of strike durations (in days) for each year in the sample. Figure 5 plots the mean duration data. It is clear that there is wide variation in durations across years with durations being particularly long during the first halves of the 1920s and 1930s. These patterns in the data are consistent with other sources. Knowles (1952, pp. 152-157) examines British industrial strike durations (all industries) during the period 1911 to 1936 . Over this period, 27.1\% of striking workers were involved in strikes lasting for 10 weeks and over, while $23.3 \%$ of strikers took part 
in strikes lasting for between 4 and 10 weeks. 1926 appears to have been a watershed year. Up to that year, $31.5 \%$ of strikes lasted for at least 10 weeks, a percentage that fell to $20.2 \%$ between 1927 and 1936. Knowles also shows that strikes involving 5000 workers or more were prevalent during the period 1911 - 1926 (85.5\% of all working days lost) but far less so between 1927 and 1947 (55.7\%). ${ }^{10}$

When mean strike durations are juxtaposed against national unemployment rates, as in Figure 5, the contrast between pre- and post-war eras is even more starkly illustrated. Pre-war unemployment is generally on a different scale from post-war experience, around the towering peak of the early 1930s Great Depression. At their lowest points - in the late 1920s and middle-to-late 1930s - average pre-war durations are comparable to post-war figures. But in the early-to-mid 1920s and at the height of the Depression, mean durations displayed extraordinary increases.

\section{Number of Unions per Strike}

In line with British unionism in general, engineering unions did not represent companies but, rather, trades and skills. Therefore, a given industrial dispute could involve more than one union. Table 4 shows the percentage of total strikes in the complete data set covered by one, two (and so on up to ten) unions. While two-thirds of strikes in the data involve a single union, clearly there are significant numbers with two or more unions participating.

\footnotetext{
${ }^{10}$ One well known long term engineering strike in which the EEF featured prominently was the apprenticeship strike of 1937. It involved 32,500 apprentices, lasted for 94 days and resulted in 406,000 working days lost (see Ryan, 2004).
} 


\section{Strike Incidence and Unemployment Rates}

\section{Strike Incidence}

Given data limitations, we cannot undertake a detailed analysis of the relationship between strike incidence and the business cycle. Data are recorded as and when company strikes take place and therefore do not report on companies for which no strikes occur. However, since we know the total numbers of EEF companies each year from a secondary source (Wigham 1973, Appendix J), we can construct a simple annual average index of strike incidence:

$$
\text { cratio }_{t}=\ln \left(\frac{\text { CSTRIKE }}{C_{t}}\right)
$$

where $C S T R I K E_{t}$ is the total number of EEF companies that experienced a strike in year $t$ and $C_{t}$ is the total number of EEF companies in year $t$.

Figure 3 shows the (unlogged) graph of this index. The incidence of strikes is quite low in the pre-war period (usually less than $2 \%$ per year) but rises and exceeds $10 \%$ in the late 1960s. Unsurprisingly, the patterns in Figure 3 are broadly similar to those of the strikes frequencies shown in Figure 2.

We regress this index on the national annual unemployment rate, $U_{t}$, and a quadratic time trend for the periods 1920 to 1970,1920 to 1938 and 1946 to 1970 . Thus, we have

$$
\text { cratio }_{t}=\alpha_{0}+\alpha_{1} U_{t}+\alpha_{2} t+\alpha_{3} t^{2}+\varepsilon_{t}
$$

where cratio $_{t}$ is defined in expression (1) and $\varepsilon_{t}$ is an error term. As in all subsequent regressions, we split strikes by whether they were primarily about pay or non-pay issues (see Tables $1 \mathrm{a}$ and $1 \mathrm{~b}$ for details of the distinctions). 
The estimates are presented in Table 5. Consistent with most of the prior literature, the evidence suggests that strike incidence is procyclical. Like that literature, the results are by no means overwhelmingly supportive. ${ }^{11}$ Standard errors are relatively large and in only one instance - pay disputes over the entire period - do we obtain statistical significance.

\section{Strike Duration and Unemployment Rates}

In contrast to strike incidence, we can make use of our company-level data to study relationships between strike duration and the cycle. We use both national and district-level unemployment rates.

The first specification is a log-linear model of strike duration which we estimate over the entire period $(1920$ - 1970) as well as the pre-war $(1920$ - 1938) and post-war (1946 - 1970) periods using the national rate of unemployment as our measure of the cycle.

$$
\log \left(\text { duration }_{i t}\right)=\beta_{0}+\beta_{1} U_{t}+\beta_{2}\left(\text { Unions }_{i t}\right)+\beta_{3} t+\beta_{4} t^{2}+\varepsilon_{i t}
$$

Here, the log duration of strike $i$ in year $t$ is expressed as a function of the national unemployment rate in year $t\left(U_{t}\right)$, the number of unions involved in the strike (Unions $\left.s_{i t}\right)^{12}$

\footnotetext{
${ }^{11}$ Harrison and Stewart (1994) provide one of the best known studies. Using Canadian data on strikes and contracts they find evidence of procyclical strike incidence, particularly in manufacturing industry, but only with respect to nonwage issues.

${ }^{12}$ There is a potential endogeneity issue with the Unions variable. As a given strike progresses through time, more workers may become affected which in turn may require more unions to become involved. Unfortunately, our strike union data does not allow us to observe such sequences. On the basis of simple regressions in which the mean annual average number of unions per strike was regressed on the unemployment rate and a quadratic time trend, there is no evidence of cyclicality. In any event, all
} 
and a quadratic in time (measured in years). The quadratic is included to take account of secular trends that impact strike duration. Because the national unemployment rate does not vary across strikes that occur in the same year, there is a clustering problem that will cause OLS variance estimates to understate the true uncertainty about the estimate (Moulton 1986). To counter this problem, we report robust standard errors that allow for observations within any year to be correlated. ${ }^{13}$

At a far more disaggregate level, the second regression model makes use of 11 years of monthly unemployment rates $(1960$ - 1970) for 54 districts (see Appendix Table 1 for a list of districts). ${ }^{14}$ For strike i in district $d$ at time $t$, it takes the form

$$
\begin{aligned}
\log \left(\text { duration }_{\text {idt }}\right)=\beta_{0}+\beta_{1} U_{d t} & +\beta_{2}\left(\text { Unions }_{\text {idt }}\right)+\beta_{3} \text { Year Dummies } \\
& +\beta_{4} \text { District Dummies }+\beta_{5} \text { Month Dummies }+\varepsilon_{i d t} .
\end{aligned}
$$

Here $U_{d t}$ is the district level unemployment rate at time $\mathrm{t}$ (where $\mathrm{t}$ is defined in months). ${ }^{15}$

There are four potential advantages of the specification in (4) compared to its more aggregate equivalent in (3). First, district-level analysis captures the likelihood that,

subsequent regressions were estimated with and without number of unions per strike as a control variable and the estimates of strike duration cyclicality were not impacted by its inclusion or exclusion.

${ }^{13}$ We also tried an alternative 2-step estimation procedure, often used in the wage cyclicality literature, to overcome the clustering problem (Solon, Barsky and Parker 1994; Devereux 2001). In the present example, the first step involves regressing strike duration on number of unions involved in the strike and a set of time dummies. In the second step, the estimated time dummies are regressed on the national unemployment rate and the quadratic time trend. The second stage regressions are weighted by the numbers of strikes occurring each year. In the event, the two methods produced very similar results.

\footnotetext{
${ }^{14}$ Unfortunately, we do not have equivalent data for the pre-1960 period. However, the 1960s are an especially interesting period to study. From Figures $2 \mathrm{a}$ and $2 \mathrm{~b}$ it is clear that the 1960s marked a period of exceptional strike incidence both within the group of EEF companies and British industry as a whole. In fact, it marked the start of an era of union militancy.

${ }^{15}$ We cluster the standard errors at the year/month/district level in these regressions. As before, we have verified that the analogous 2-step approach gives very similar results for coefficients and standard errors.
} 
in many instances, it is local labour market conditions that matter most to unions and workers. Second, introducing cross-sectional variation allows us to include both year fixed effects and district fixed effects, while still identifying the effects of the unemployment rate. Thus, we can be sure that some unknown year-specific factor that impacts strike durations is not confounding our estimates. Third, from Table 2 we note that the average strike in the post-war period lasted for about 6 days. In many instances, the decision over the best time to stay out may well have been quite finely tuned to the perceived state of the cycle within a relatively short interval of time. This may not be captured by a rate of unemployment averaged over a complete year. Fourth, embracing seasonality may well be an important consideration. In their analysis of the seasonal patterns of UK strikes between 1946 and 1973, Durcan et al. (1983) show that spring and autumn are the two periods in the year when major stoppages are likely to begin.

There is a particular value of employing district rates in the post-war period because, as shown in Figure 5, during that period the national rate of unemployment goes no higher than $2 \%$ and so is suggestive of a period of very gentle business cycles. ${ }^{16}$ However, there is a great deal of district variation around this aggregate trend. Using our 1960-1970 monthly unemployment data for 54 districts we regressed the district unemployment rate on district, monthly and annual dummies and plotted the residuals. Four representative examples - from Scotland, Northern Ireland, the North of England (N.E. Coast) and the Midlands (Coventry) - are shown in Figure 6. Recall from Figure 2b that strike activity was especially prevalent at this time as was trade union militancy. One of the centres of militancy was in the Midlands, dominated by the automotive

\footnotetext{
${ }^{16}$ This is not an issue for the pre-war estimates as there are enormous cyclical variations during that period.
} 
industry. In Figure 6, Coventry represents this region and it is quite clear that this city experienced several marked unemployment cycles over these 11 years. The other districts shown - which were not the most volatile of the remaining districts - also display systematic movements with high points in late 1962/early 1963 and towards the end of the period as well as a fairly pronounced trough in 1966.

We can classify strikes by both company and by union involvement. Therefore, in regression equations (3) and (4) above, we can add company and union fixed effects in the estimating equations. As we saw in Table 5, strike incidence appears to be procyclical, suggesting that, to some limited degree, unions and companies may have been more willing to engage in brinkmanship when labour market conditions are good. However, it has the further implication that the types of companies and unions that are engaged in strikes may differ systematically over the business cycle. This is the rationale for inclusion of company and union fixed effects in estimation. With company effects, we are essentially comparing strike durations across strikes that occur in the same company but at different points in the business cycle. With union effects, we are controlling for the aggressiveness of the union.

There are 1909 different companies in our data set of which 49\% experienced only 1 strike within the full data coverage. Of the remainder, 16\% percent featured twice, 8\% 3-times, 6\% 4-times, 4\% 5-times, 3\% 6-times, 2\% 7-times, and about 1\% featured 8times or more. At the extreme right of the distribution there are 12 examples of companies featuring 100 times or more. On the union side, our data include 94 different single unions involved in strikes while additional strike actions featured 2 or more unions. Where more than one union was involved, the data identify the leading union. 
Therefore, we decided to code unions from 1 to 94 for single union involvement and then 95 to 147 where one of these single unions is identified as leading one or more additional unions in a given strike. Appendix Table 3 shows the strike frequency distribution pertaining to these 147 distinct union cells. In $29 \%$ of cases there was only one strike incident, while $16 \%$ involved 2 incidents, $4 \% 3$ incidents and so on.

The estimates from regression model (3) - that incorporates annual national unemployment rates - are shown in Table $6 .{ }^{17}$ Results for the whole period and for the pre-war period reveal only one instance of significant countercyclicality in strike durations. This is obtained in relation to pay-related disputes and after controlling for union fixed effects. Somewhat more comprehensively, pay-related disputes also exhibit countercyclical durations in the post-war era. While the standard errors are large, there is an indication that non-pay disputes are also countercyclical during the later period. ${ }^{18}$

For the period 1960 to 1970, we repeated the durations regressions using the extended specification shown in equation (4). These estimates for the district unemployment rate are in Table 7. We present results with year fixed effects in addition to estimates with a quadratic in year and we obtain strong evidence that non-pay strike durations are countercyclical. Recall that about $50 \%$ of strikes at this time involved non-

\footnotetext{
${ }^{17}$ We do not report coefficient values for the Unions variable in the table as this variable is likely endogenously determined and so subject to bias. However, the coefficient on it is generally negative, indicating that strike durations are shorter when more unions are involved. This supports the notion that a single union leading a dispute can more efficiently muster the solidarity and cohesion required to 'stay the course' in order to meet its members' objectives. However, given the number of unions involved may be correlated with many other factors, caution is warranted in interpretation.

${ }^{18}$ One concern is that our results may be model-dependent and there are many more sophisticated duration models that we could have used. The loglinear model we have used is exactly equivalent to an accelerated failure time hazard model in which the error is assumed to be normally distributed. We have experimented with many other hazard specifications including weibull, exponential, log-normal, log-logistic, gamma, and gompertz and found similar estimates. The derivatives were generally similar to the estimates we report in the tables.
} 
pay issues (see Figure 4). Generally, we obtain similar results with respect to OLS and union fixed effects regressions. Interestingly, the addition of company and union fixed effects eliminates any evidence that pay-related strike durations are countercyclical. This suggests that there were changes in the composition of unions and firms involved in pay strikes over the business cycle and that the inability of previous studies to include union and company fixed effects may have led to bias.

\section{Union Strike Success and Unemployment Rates}

In order to improve the probability of gaining from a strike, is it better for the union to strike towards the peak of a cycle (when company profit and demand pressures are relatively high) while resisting action during troughs (when strikers and their families face less favourable alternative labour market options)? The EEF data record the outcomes of strikes, although in somewhat less detail than the causes. The outcomes were allocated under the various headings shown in Appendix Table 4. Some of these allocations are, of necessity, somewhat tentative. In other words, it was difficult in some instances to decide whether or not a given strike was unequivocally successful or unsuccessful. For the categories labelled 'successful', however, it was reasonably clear that most strikes achieved a partial gain or a completely successful resolution for the union.

Let $O S_{i t}$ be the outcome of strike $i$ at time $t$ such that $O S_{i t}=1$ if a strike is 'successful' (all the $O S_{\mathrm{i}}$ 's listed in Table 8) and $O S_{i t}=0$ otherwise. We then specify a linear probability regression model

$$
O S_{i t}=\gamma_{0}+\gamma_{1} U_{t}+\gamma_{2}(\text { Unions })+\gamma_{3} t+\gamma_{4} t^{2}+\varepsilon_{i t}
$$


that we estimate by OLS in the same way as in the duration regressions. As can be seen in Table 8, our evidence points to procyclical successful outcomes, both in the pre-war and the post-war period. The pre-war finding of procyclicality is robust to company and union fixed effects in the case of pay strikes but not for non-pay strikes. In the post-war period, the procyclical finding is statistically significant for non-pay strikes when union and company fixed effects are included. The magnitude of the effect for pay strikes is similar but the standard error is higher so it is not statistically significant. The magnitudes are quite big - in the pre-war period a one unit increase in the unemployment rate reduces the probability that a pay strike has a successful outcome by .03 (from a baseline of 0.40). The equivalent effect of a one point increase in unemployment in the post-war period is about .06 for both types of strikes (from a baseline of 0.75 ). ${ }^{19}$

\section{Conclusions}

In this paper, we have compiled a unique historical dataset that records strike activity in the British engineering industry from 1920 to 1970 . A strength of these data is that they include a homogenous set of companies and workers, covering a long period with varying labour market conditions. We show that the incidence and causes of strikes in engineering over these years follow patterns that are quite reflective of strike behaviour in British industry as a whole. However, unlike earlier broadly based cross-industry studies, the engineering data allow us to study the cyclicality of strike durations and outcomes after controlling for company, union, time (month and year), and local labour market effects.

\footnotetext{
${ }^{19}$ We have also carried out this estimation using the 1960-1970 district level unemployment rates sample. We found negative estimates that were never statistically significant.
} 
We use unemployment rates as our measure of the cycle primarily because they allow two levels of aggregation in the regression analyses - i.e. annual national and monthly district. The great advantage of the latter is that the district unemployment rate data are matched to coincide with the location and timing of the EEF company strikes. We are forced to examine strike incidence at a quite aggregate level and find, in line with other studies, fairly weak support for procyclicality. Like the previous literature, we find evidence for countercyclical strike durations, both for pay and non-pay related strikes. However, in the post-war period, the magnitude of this effect is much reduced for pay strikes when union and firm fixed effects are included. These findings suggest that it is important when studying strike durations to take account of differences in the composition of companies and unions that are involved in strikes at different points of the business cycle.

We also find that strike outcomes tend to be more favourable to unions when the national unemployment rate is lower. The evidence for this is particularly strong for paystrikes in the pre-war period. This is perhaps unsurprising given the extremely adverse economic conditions during the Great Depression years. The evidence on strike success rates and the business cycle is weaker post-war but does indicate greater union success when the national unemployment rate is lower. 


\section{References}

Booth, A and R Cressy. 1990. Strikes with asymmetric information: theory and evidence. Oxford Bulletin of Economics and Statistics 52, 269-291.

Cramton, P C, and J S Tracy. 2003. Unions, Bargaining and Strikes. In J T Addison and C Schnabel (eds.), International Handbook of Trade Unions, Cheltenham. UK: Edward Elgar.

Denham, J and P McDonald. 1996. Unemployment statistics from 1881 to the present day. Labour Market Trends 104 (January), 5 - 18.

Devereux, P J. 2001. The cyclicality of real wages within employer-employee matches. Industrial and Labor Relations Review, Vol. 54, July, pp. 835-850.

Durcan, J W, W E J McCarthy and G P Redman. 1983. Strikes in post-war Britain. A study of stoppages of work due to industrial disputes, 1946 - 1973. London: George Allen and Unwin

Farber, H.1978. Bargaining theory, wage outcomes, and the occurrence of strikes: an econometric analysis. American Economic Review 68, 262-271.

Forchheimer, K. 1948. “Some international aspects of the strike movement.” Bulletin of the Oxford Institute of Statistics 10, 9-24.

Galambos, P and E W Evans. 1977. Work stoppages in the United Kingdom 1965 1970: a quantitative study. In E W Evans and S W Creigh (eds), Industrial Conflict in Britain. London: Frank Cass.

Harrison, A and M Stewart. 1994. Is strike behavior cyclical? Journal of Labor Economics 12, 524-553.

Harrison, A, and M Stewart. 1989. Cyclical Fluctuations in Strike Durations. American Economic Review, Vol. 79, No. 4 (September), pp. 827-841.

Hart, R A and D I MacKay. 1975. Engineering Earnings in Britain: 1914-1966. Journal of the Royal Statistical Society 138, (Series A), 32-50.

Hicks J. 1932. The Theory of Wages. London. Macmillan and Co.

Ingram, P, D Metcalf and J Wadsworth. 1993. Strike incidence in British Manufacturing in the 1980s. Industrial and Labor Relations Review 46, 704-717.

Kennan, J. 1985. The Duration of Contract Strikes in U.S. Manufacturing. Journal of Econometrics, Vol. 28, April, pp. 5-28. 
Kennan, J. 1986. The economics of strikes. In Handbook of Labor Economics, O Ashenfelter and R Layard (eds.), Amsterdam and New York: North Holland.

Kennan, J and R Wilson. 1993. Bargaining with Private Information. Journal of Economic Literature 31, 45-104.

Knowles, K G J C. 1952. Strikes - a study in industrial conflict. Oxford, Basil Blackwell.

Knowles, K G J C. and T P Hill. 1954. The structure of engineering earnings. Bulletin of the Oxford University Institute of Statistics 16, 272-328.

McCarthy, W E J. 1977. The reasons given for striking. An analysis of official statistics. 1945-1957. In E W Evans and S W Creigh (eds), Industrial Conflict in Britain. London: Frank Cass.

McConnell, S. 1990. Cyclical fluctuations in strike activity. Industrial and Labor Relations Review 44, 130-143.

Moulton, Brent R. 1986. Random group effects and the precision of regression estimates. Journal of Econometrics, Vol. 32, August, pp. 385-397.

Ryan, P. 2004. Apprentice strikes in the Twentieth-Century UK engineering and shipbuilding industries. Historical Studies in Industrial Relations 18, 1 - 63.

Solon, G, R B Barsky and J A. Parker. 1994. Measuring the cyclicality of real wages: how important is composition bias? Quarterly Journal of Economics 109, No. 1, pp. 1-26.

Vanderkamp, J. 1970. Economic activity and strikes in Canada. Industrial Relations 9, 215-230.

Wigham, E. 1973. The power to manage. A history of the Engineering Employers' Federation. London: Macmillan. 


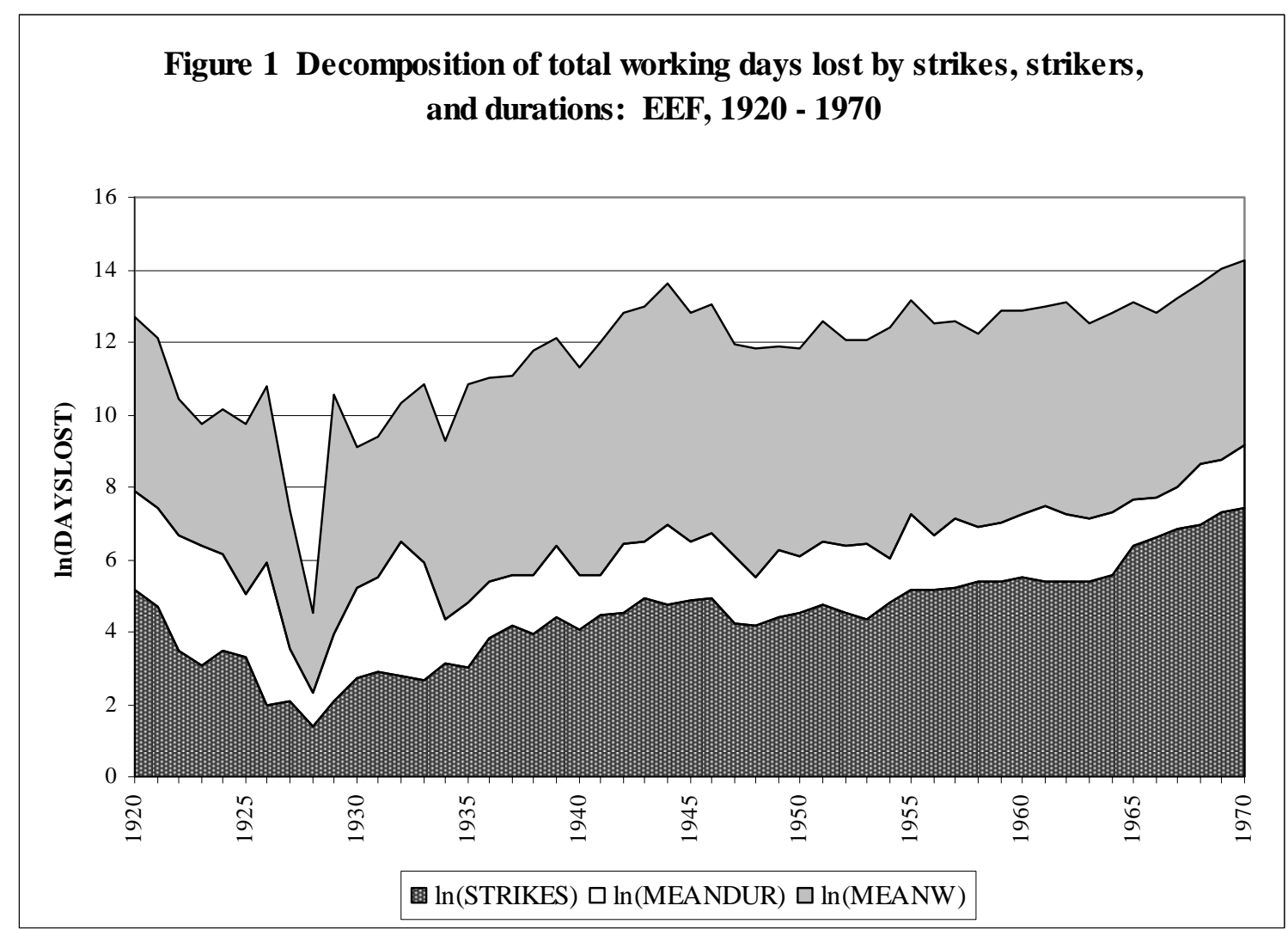

Figure 1 shows the annual decomposition of total days lost due to EEF strikes subdivided into three factors. Let DAYSLOST = total working days lost (per-period), STRIKES = number of strikes, MEANDUR = average strike duration, and MEANW = average number of workers involved in strikes; then $\ln ($ DAYSLOST $)=\ln ($ STRIKES $)+$ $\ln ($ MEANDUR $)+\ln ($ MEANW $)$. The latter expression is graphed in Figure 1.

Source: Authors' calculations 


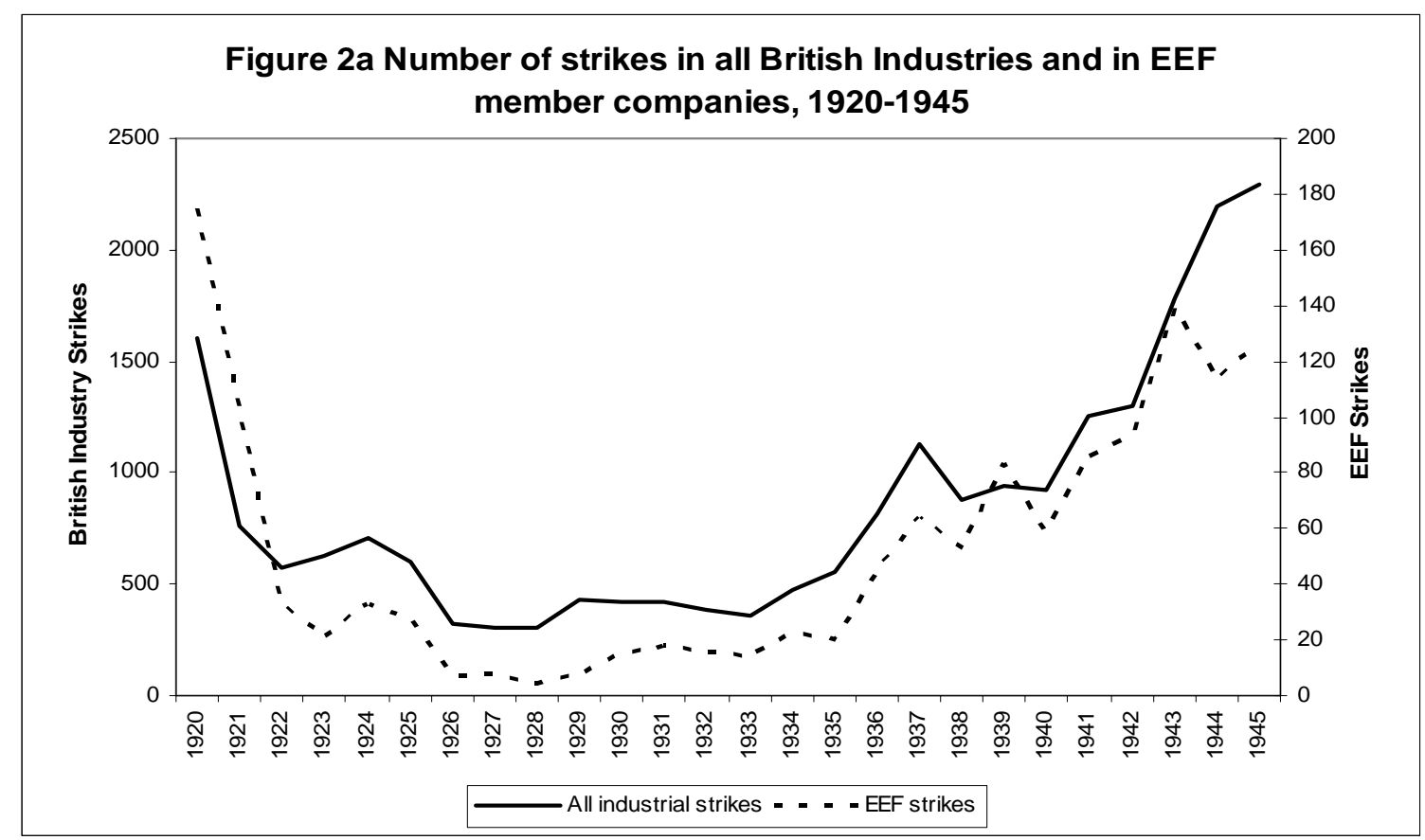

Source: Data for all-industries graph taken from Knowles (1952, Statistical Appendix Table 1, p.310). (For 1926, all industries data exclude the General Strike. It lasted from 312 May and, while initiated through an employers' lock out of coal miners, involved a wide cross-section of industry including building, printing, dock, iron, steel, metal, heavy chemical, transport and railway workers.)

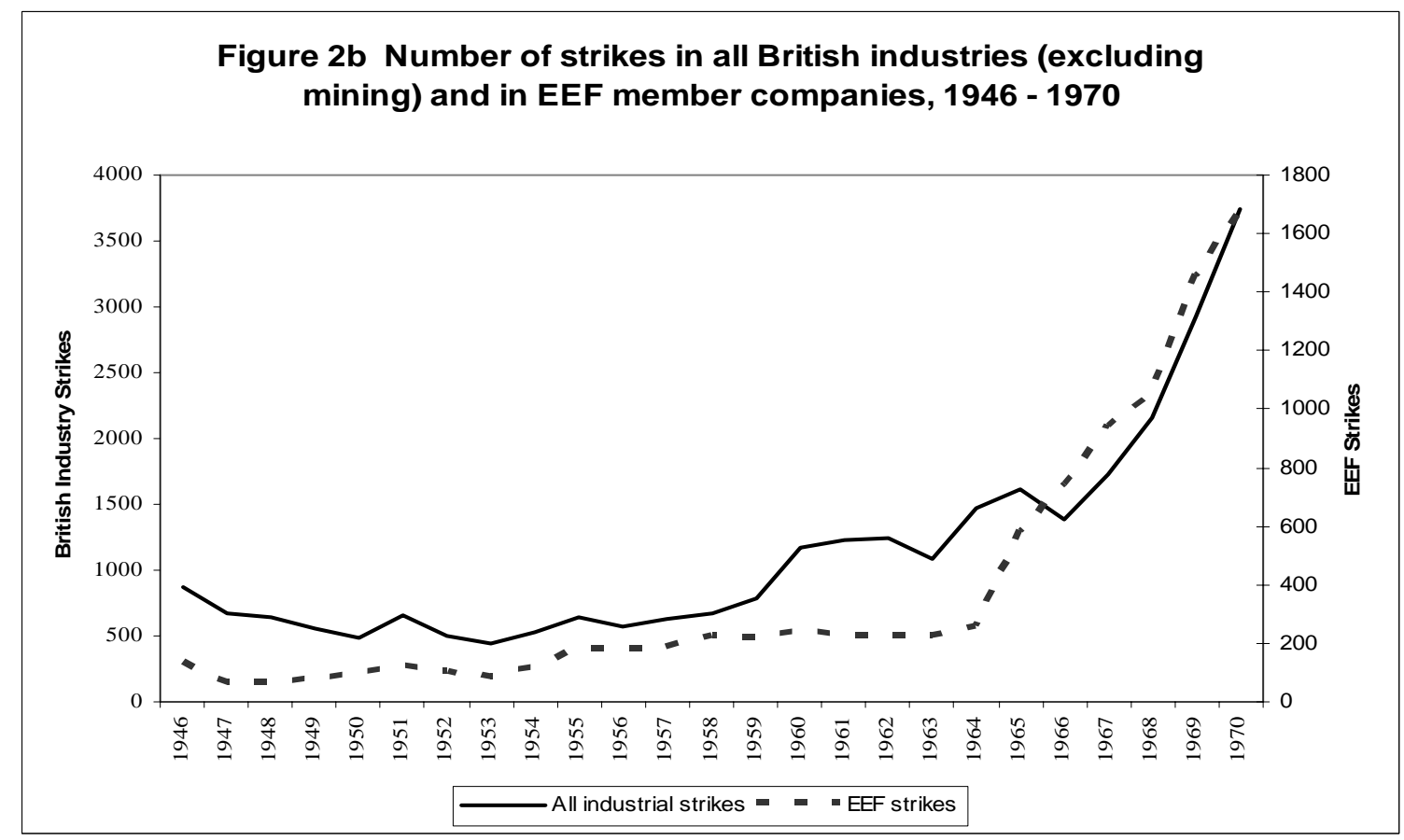

Source: Data for all-industries graph from Durcan et al. (1983, Table 6.1, p.174) 


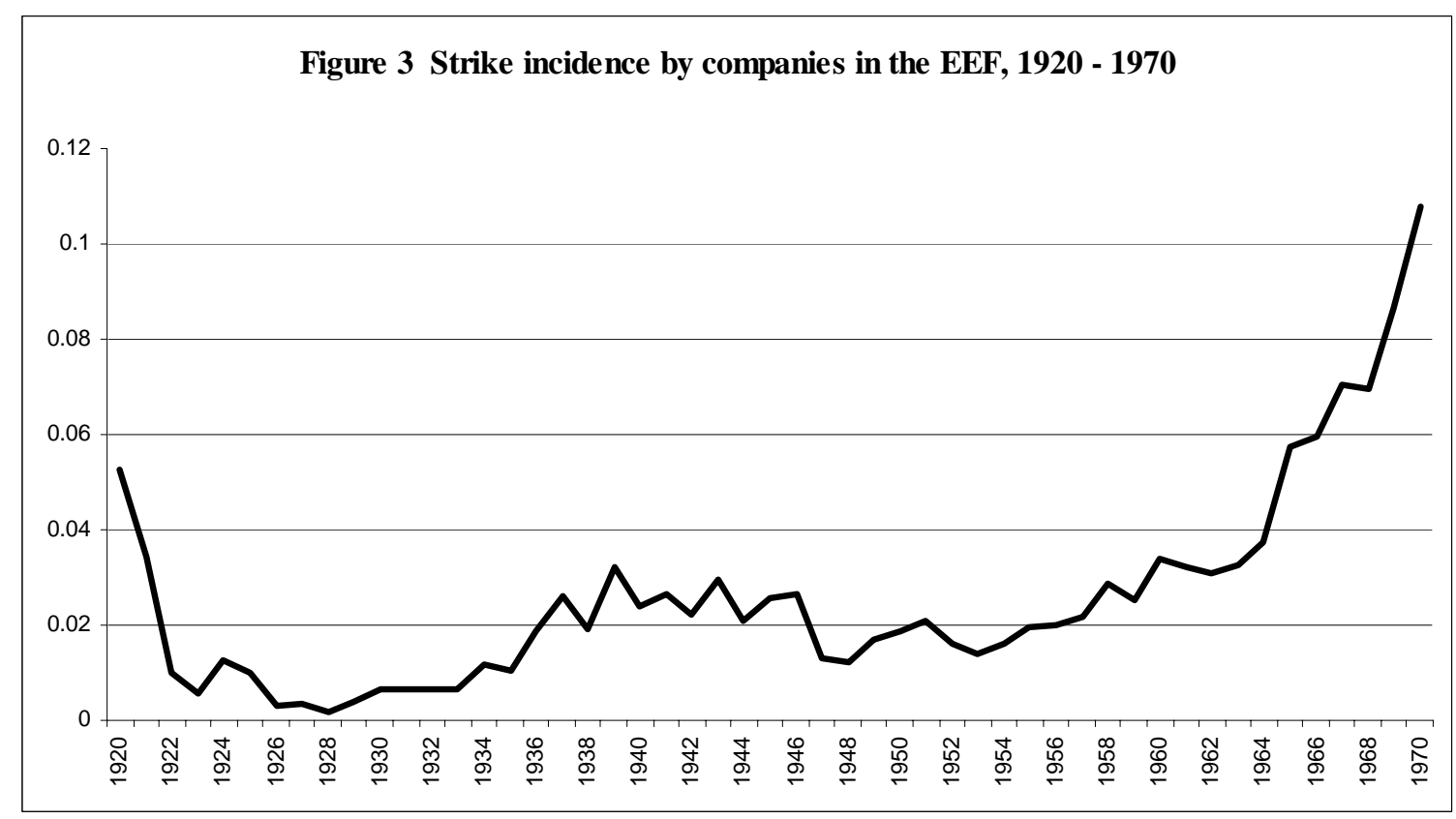

Strike incidence is calculated as the total number of EEF companies that experienced a strike in year $t$ divided by the total number of EEF companies in year $t$.

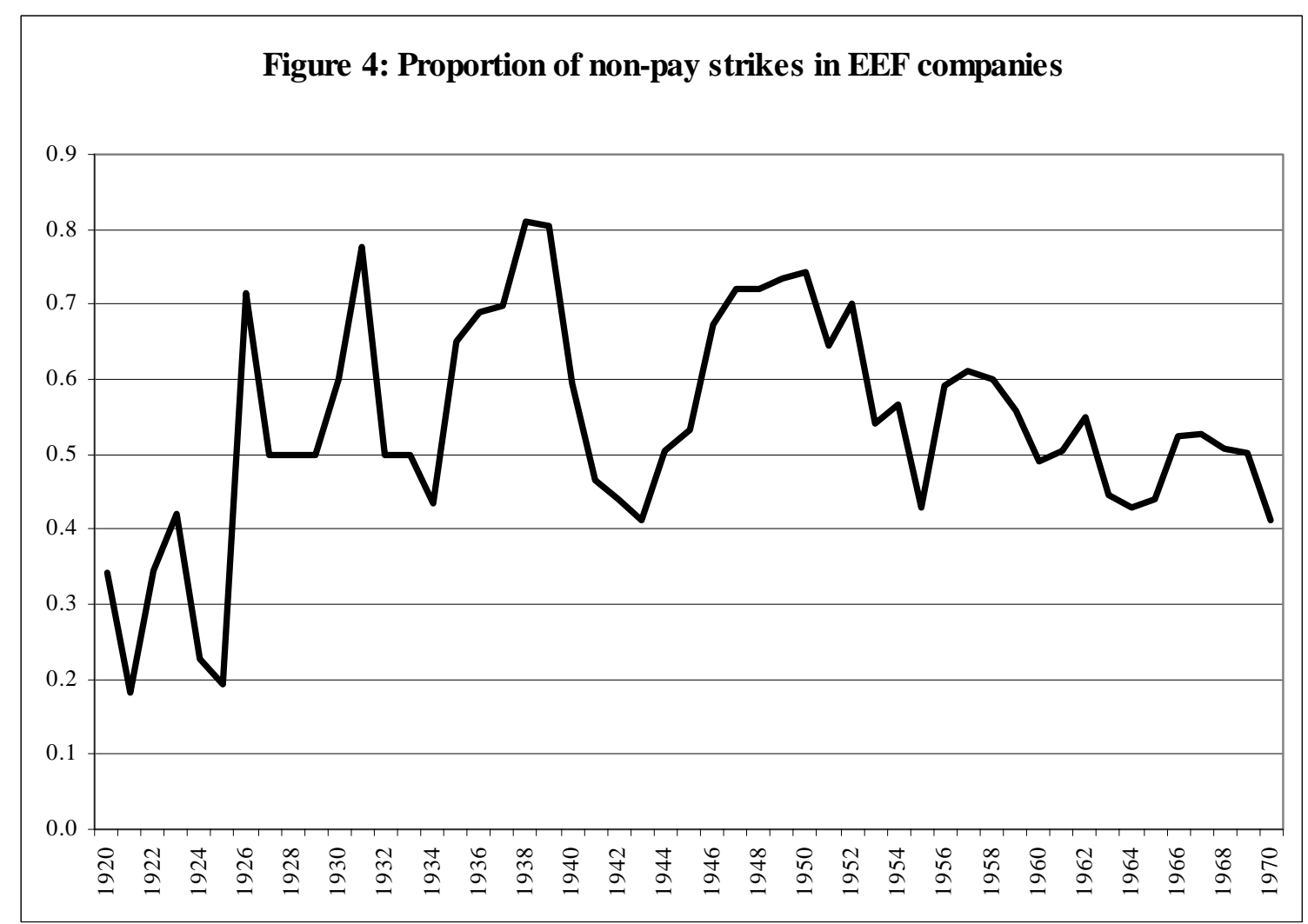




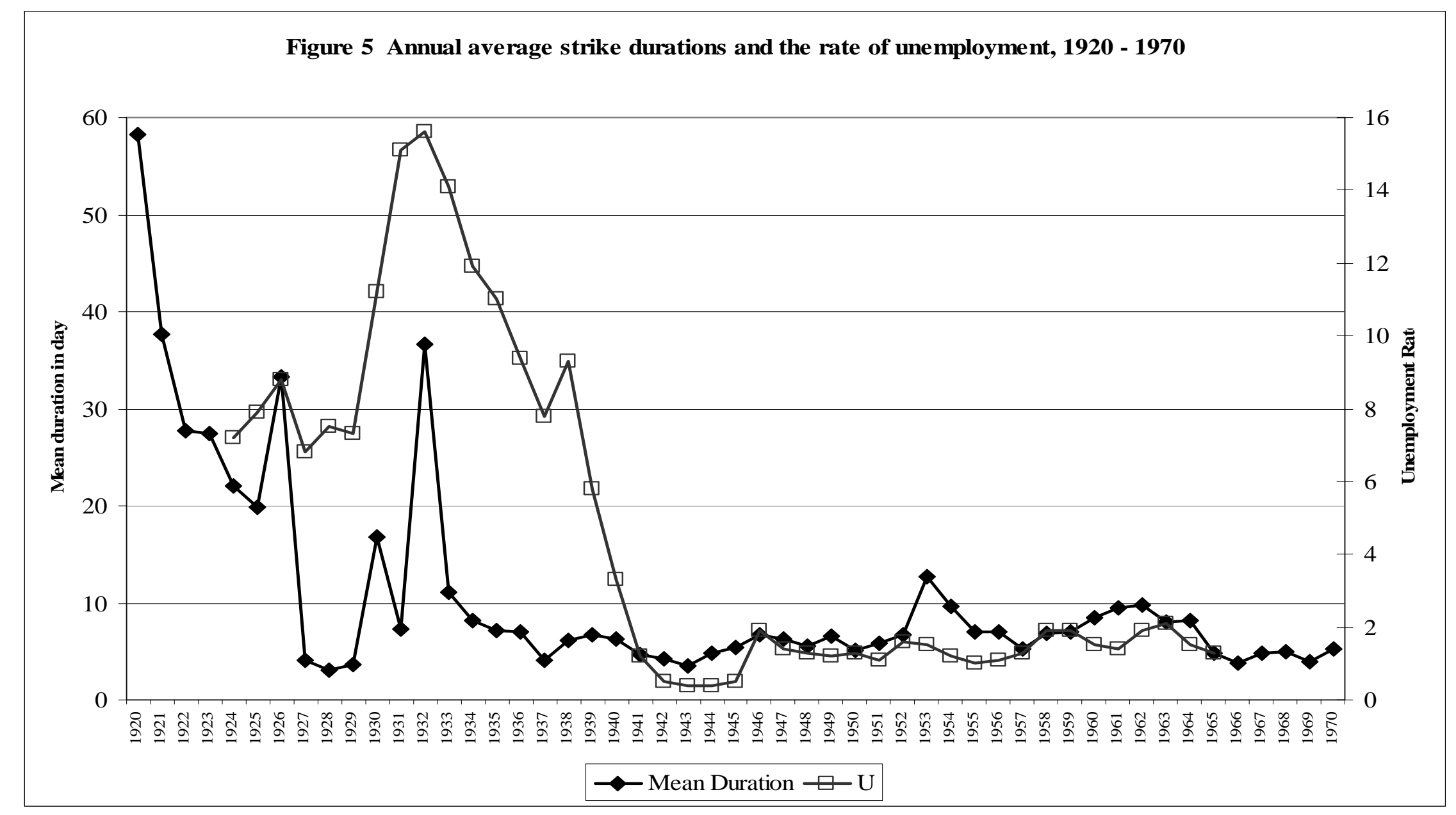

Source of Unemployment Rates: Denham and McDonald (1996) 


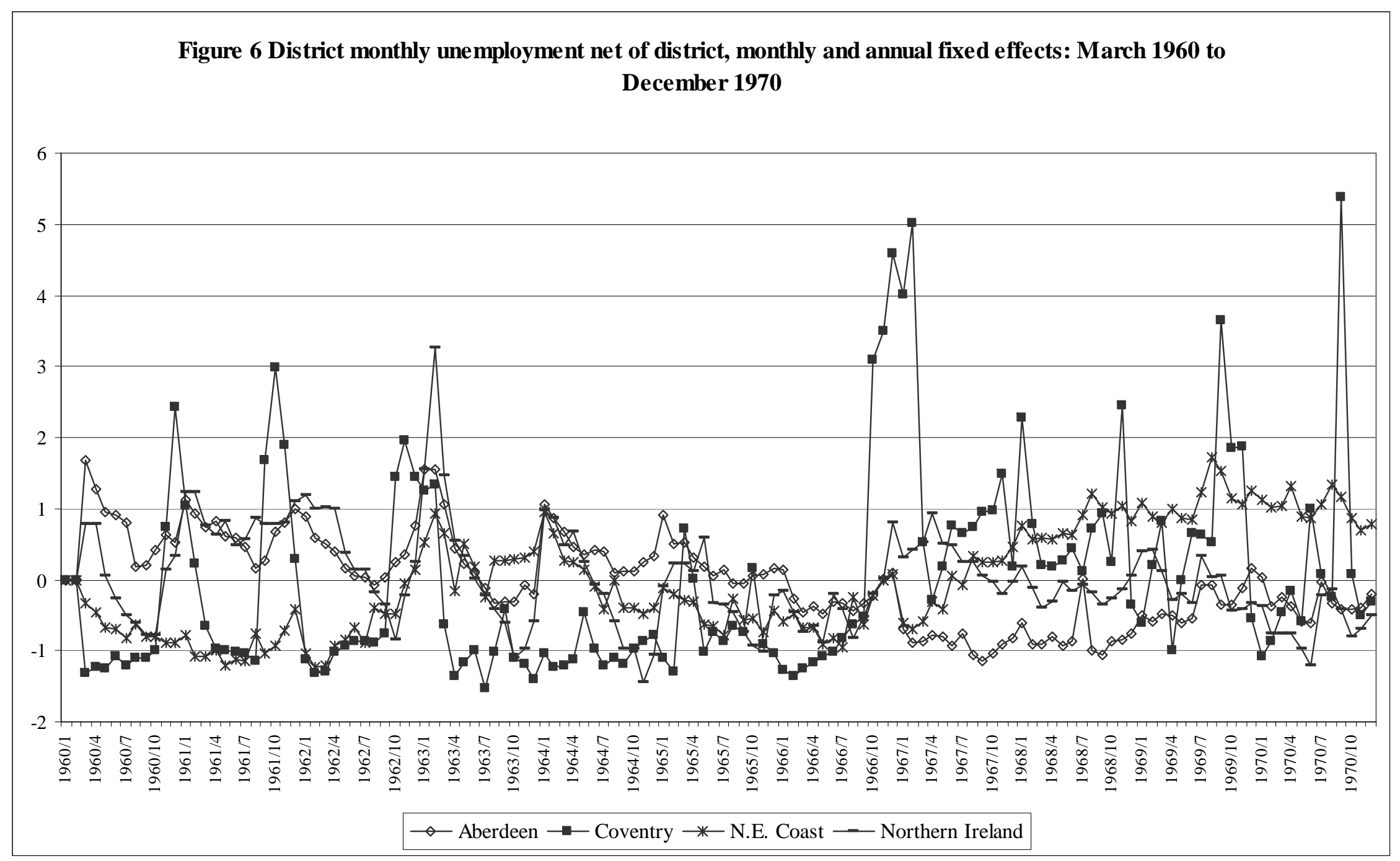

This figure is constructed by regressing the district unemployment rate on district, monthly and annual dummies and plotting the residuals. 
Table 1a Causes of Pay-Related Strikes, 1920 - 1970

\begin{tabular}{|c|c|c|c|}
\hline PAY ISSUES & $\begin{array}{l}\mathbf{1 9 2 0 - 1 9 7 0} \\
\text { Percentage } \\
\end{array}$ & $\begin{array}{l}\mathbf{1 9 2 0 - 1 9 3 8} \\
\text { Percentage }\end{array}$ & $\begin{array}{l}\text { 1946-1970 } \\
\text { Percentage }\end{array}$ \\
\hline Wages & 49.82 & 61.94 & 49.97 \\
\hline Bonuses & 17.09 & 7.96 & 17.62 \\
\hline Piece Rates & 14.14 & 12.19 & 14.01 \\
\hline Systems of pay (e.g. rate fixing, abolition of piecework system) & 6.78 & 5.72 & 5.79 \\
\hline Payment for Time Lost (mainly waiting time payments due to downtime) & 5.07 & 1.49 & 5.61 \\
\hline Relative Pay (mainly disputes over pay differentials among skill groups & 3.32 & 4.48 & 3.26 \\
\hline Holiday Pay & 1.97 & - & 2.27 \\
\hline Shift/Night Rates & 0.11 & 0.5 & 0.06 \\
\hline Overtime & 0.09 & & 0.09 \\
\hline Misc. Pay-related & 1.6 & 5.72 & 1.32 \\
\hline
\end{tabular}


Table 1b Causes of Non-Pay Strikes, 1920 - 1970

\begin{tabular}{|c|c|c|c|}
\hline NON-PAY ISSUES & $\begin{array}{l}\mathbf{1 9 2 0 - 1 9 7 0} \\
\text { Percentage }\end{array}$ & $\begin{array}{l}\mathbf{1 9 2 0 - 1 9 3 8} \\
\text { Percentage }\end{array}$ & $\begin{array}{l}\mathbf{1 9 4 6 - 1 9 7 0} \\
\text { Percentage }\end{array}$ \\
\hline Wrongful dismissal & 14.13 & 14.1 & 13.79 \\
\hline Union-related issues (e.g. employment of non-union workers, inter-union disputes) & 10.46 & 20.51 & 9.46 \\
\hline Treatment of worker(s) & 9.63 & 2.24 & 9.75 \\
\hline Work Environment (e.g. work conditions too cold or too hot) & 8.27 & 0.96 & 8.89 \\
\hline Work flexibility (e.g. switching labour to alternative tasks, cover for absenteeism, work reorganisation) & 7.41 & 0.64 & 8.29 \\
\hline Job demarcation & 7.06 & 21.79 & 6.17 \\
\hline Working hours & 5.87 & 3.85 & 6.19 \\
\hline Redundancy & 5.61 & 1.28 & 6.01 \\
\hline Timing of job tasks (e.g. timing of piecework; objections to work time investigations) & 4.95 & 6.41 & 4.92 \\
\hline Sympathy with others (largely sympathy with workers directly involved in strikes/disputes) & 4.75 & 9.62 & 4.48 \\
\hline Supervision (e.g. objection to attitude of foreman) & 4.38 & 3.21 & 4.16 \\
\hline Delay in/ refusal of management to open negotiations & 3.56 & - & 4 \\
\hline Production constraints (e.g. shortage of work, partial plant shutdown, manning problems) & 3.47 & 2.56 & 3.56 \\
\hline Attendance at union meeting (e.g. attendance at an unofficial meeting during working hours) & 2.46 & - & 2.8 \\
\hline Use of outside labour & 0.81 & 2.24 & 0.75 \\
\hline Apprentices (e.g. ratios of apprentices to skilled journeymen) & 0.42 & 4.17 & 0.15 \\
\hline Miscellaneous & 6.73 & 6.41 & 6.61 \\
\hline
\end{tabular}


Table 2: Mean and median strike durations (days) by period and north/south

\begin{tabular}{|l|l|cccc|}
\hline \multirow{5}{*}{ Pre-war } & & \multicolumn{4}{|c|}{ Issue } \\
\cline { 3 - 6 } & $\begin{array}{c}\text { Wages } \\
\text { Only }\end{array}$ & All Pay & Non-Pay & All Issues \\
\cline { 2 - 6 } & Mean & 60.03 & 43.51 & 9.33 & 28.41 \\
& $\begin{array}{l}\text { Median } \\
\text { No. of } \\
\text { War }\end{array}$ & 23 & 13 & 4 & 6 \\
\cline { 2 - 6 } & strikes & 237 & 383 & 303 & 686 \\
\cline { 2 - 6 } Post-war & 6.36 & 5.02 & 4.86 & 4.94 \\
& $\begin{array}{l}\text { Median } \\
\text { No. of }\end{array}$ & 2.5 & 2.5 & 2 & 2 \\
& $\begin{array}{l}\text { Non } \\
\text { strikes }\end{array}$ & 110 & 333 & 360 & 693 \\
\cline { 2 - 6 } & $\begin{array}{l}\text { Mean } \\
\text { Median }\end{array}$ & 8.23 & 6.71 & 4.49 & 5.58 \\
& $\begin{array}{l}\text { No. of } \\
\text { strikes }\end{array}$ & 2311 & 2 & 1.5 & 2 \\
\hline
\end{tabular}

\begin{tabular}{|l|l|cccc|}
\hline \multirow{4}{*}{ North } & & \multicolumn{4}{|c|}{ Issue } \\
\cline { 3 - 6 } & & $\begin{array}{l}\text { Wage } \\
\text { Only }\end{array}$ & Wages Plus & Nonwage & All Issues \\
\cline { 2 - 6 } & $\begin{array}{l}\text { Mean } \\
\text { Median }\end{array}$ & 20.83 & 15.12 & 7.63 & 11.58 \\
& $\begin{array}{l}\text { No. of } \\
\text { South }\end{array}$ & 5 & 4 & 3 & 3.5 \\
& strikes & 1,095 & 2,080 & 1,869 & 3,949 \\
\cline { 2 - 7 } & $\begin{array}{l}\text { Mean } \\
\text { Median }\end{array}$ & 7.13 & 5.50 & 3.30 & 4.35 \\
& $\begin{array}{l}\text { No. of } \\
\text { strikes }\end{array}$ & 1,563 & 2 & 1 & 1 \\
\hline
\end{tabular}


Table 3: Description of Strike Activity (1920 - 1970)

\begin{tabular}{|c|c|c|c|c|c|c|c|c|}
\hline \multirow[b]{3}{*}{1920} & \multirow{2}{*}{$\begin{array}{l}\text { No. of } \\
\text { strikes }\end{array}$} & \multirow{2}{*}{$\begin{array}{c}\text { Mean } \\
\text { Duration }\end{array}$} & \multirow{2}{*}{$\begin{array}{l}\text { Median } \\
\text { Duration }\end{array}$} & \multicolumn{5}{|c|}{ Survival rates } \\
\hline & & & & Day5 & Day25 & Day50 & Day75 & Day100 \\
\hline & 175 & 58.3 & 10 & 0.7 & 0.33 & 0.27 & 0.26 & 0.23 \\
\hline 1921 & 103 & 37.61 & 11 & 0.68 & 0.41 & 0.34 & 0.21 & 0.12 \\
\hline 1922 & 33 & 27.7 & 20 & 0.79 & 0.42 & 0.21 & 0.12 & 0 \\
\hline 1923 & 21 & 27.48 & 19 & 0.71 & 0.33 & 0.24 & 0.05 & 0.05 \\
\hline 1924 & 33 & 22.09 & 8 & 0.64 & 0.27 & 0.09 & 0.09 & 0 \\
\hline 1925 & 27 & 19.81 & 16 & 0.78 & 0.48 & 0.07 & 0 & 0 \\
\hline 1926 & 7 & 33.29 & 2 & 0.29 & 0.29 & 0.29 & 0.14 & 0.14 \\
\hline 1927 & 8 & 4.13 & 4 & 0.25 & 0 & 0 & 0 & 0 \\
\hline 1928 & 4 & 3 & 2.5 & 0.25 & 0 & 0 & 0 & 0 \\
\hline 1929 & 8 & 3.69 & 2.5 & 0.25 & 0 & 0 & 0 & 0 \\
\hline 1930 & 15 & 16.73 & 6 & 0.6 & 0.13 & 0.07 & 0.07 & 0.07 \\
\hline 1931 & 18 & 7.28 & 3 & 0.33 & 0.11 & 0 & 0 & 0 \\
\hline 1932 & 16 & 36.69 & 29 & 0.81 & 0.56 & 0.38 & 0.19 & 0 \\
\hline 1933 & 14 & 11.03 & 6.25 & 0.64 & 0.07 & 0.07 & 0 & 0 \\
\hline 1934 & 23 & 8.18 & 3 & 0.35 & 0.09 & 0.04 & 0 & 0 \\
\hline 1935 & 20 & 7.18 & 4 & 0.45 & 0.05 & 0 & 0 & 0 \\
\hline 1936 & 45 & 6.96 & 3 & 0.36 & 0.09 & 0 & 0 & 0 \\
\hline 1937 & 64 & 4.07 & 3 & 0.28 & 0.02 & 0 & 0 & 0 \\
\hline 1938 & 53 & 6.14 & 2 & 0.3 & 0.04 & 0.02 & 0 & 0 \\
\hline 1939 & 83 & 6.78 & 3 & 0.39 & 0.06 & 0.01 & 0 & 0 \\
\hline 1940 & 59 & 6.33 & 3 & 0.34 & 0.05 & 0 & 0 & 0 \\
\hline 1941 & 86 & 4.74 & 2 & 0.27 & 0.02 & 0.01 & 0.01 & 0 \\
\hline 1942 & 94 & 4.18 & 2 & 0.23 & 0.02 & 0 & 0 & 0 \\
\hline 1943 & 139 & 3.48 & 2 & 0.19 & 0.02 & 0 & 0 & 0 \\
\hline 1944 & 113 & 4.77 & 2 & 0.28 & 0.03 & 0 & 0 & 0 \\
\hline 1945 & 127 & 5.46 & 3 & 0.39 & 0.02 & 0 & 0 & 0 \\
\hline 1946 & 135 & 6.73 & 3 & 0.36 & 0.07 & 0.01 & 0 & 0 \\
\hline 1947 & 67 & 6.24 & 2 & 0.37 & 0.04 & 0 & 0 & 0 \\
\hline 1948 & 66 & 5.52 & 2.25 & 0.32 & 0.02 & 0 & 0 & 0 \\
\hline 1949 & 80 & 6.64 & 3.5 & 0.39 & 0.05 & 0 & 0 & 0 \\
\hline 1950 & 93 & 5.08 & 2 & 0.27 & 0.04 & 0 & 0 & 0 \\
\hline 1951 & 115 & 5.91 & 2 & 0.36 & 0.07 & 0 & 0 & 0 \\
\hline 1952 & 94 & 6.65 & 2 & 0.3 & 0.11 & 0 & 0 & 0 \\
\hline 1953 & 77 & 12.76 & 2.5 & 0.39 & 0.13 & 0.05 & 0.05 & 0.04 \\
\hline 1954 & 120 & 9.4 & 1.5 & 0.33 & 0.14 & 0.05 & 0.01 & 0 \\
\hline 1955 & 172 & 4.7 & 1 & 0.26 & 0.03 & 0 & 0 & 0 \\
\hline 1956 & 179 & 6.94 & 1.5 & 0.25 & 0.07 & 0.02 & 0.02 & 0 \\
\hline
\end{tabular}




\begin{tabular}{|l|ccc|ccccc|}
1957 & 189 & 5.31 & 1 & 0.22 & 0.04 & 0.02 & 0.01 & 0.01 \\
1958 & 225 & 6.85 & 2 & 0.3 & 0.06 & 0.02 & 0.01 & 0.01 \\
1959 & 219 & 7.04 & 2.5 & 0.33 & 0.07 & 0.03 & 0 & 0 \\
1960 & 240 & 8.31 & 4 & 0.45 & 0.11 & 0.01 & 0.01 & 0 \\
1961 & 222 & 9.55 & 5 & 0.55 & 0.09 & 0.02 & 0.01 & 0 \\
1962 & 225 & 9.83 & 4 & 0.49 & 0.1 & 0.03 & 0.01 & 0 \\
1963 & 220 & 8.06 & 3.25 & 0.41 & 0.1 & 0.02 & 0.01 & 0 \\
1964 & 251 & 8.26 & 4 & 0.44 & 0.09 & 0.03 & 0 & 0 \\
1965 & 585 & 4.82 & 2 & 0.26 & 0.04 & 0.01 & 0 & 0 \\
1966 & 744 & 3.83 & 1.5 & 0.18 & 0.02 & 0.01 & 0.01 & 0 \\
1967 & 942 & 4.86 & 1.5 & 0.21 & 0.04 & 0.01 & 0.01 & 0 \\
1968 & 1054 & 5.01 & 1.5 & 0.26 & 0.03 & 0.01 & 0 & 0 \\
1969 & 1452 & 4.01 & 1 & 0.2 & 0.03 & 0.01 & 0 & 0 \\
1970 & 1678 & 5.26 & 1.5 & 0.26 & 0.05 & 0.01 & 0 & 0 \\
\hline
\end{tabular}


Table 4 Number of unions participating in strikes, 1920 - 1970

\begin{tabular}{|c|c|c|}
\hline $\begin{array}{c}\text { Number of Unions } \\
\text { per Strike }\end{array}$ & Total Number & Percentage of Total \\
\hline 1 & 7102 & 66.9 \\
2 & 1823 & 17.2 \\
3 & 1169 & 11.0 \\
4 & 288 & 2.7 \\
5 & 119 & 1.1 \\
6 & 51 & 0.5 \\
7 or more & 56 & 0.5 \\
\hline \multicolumn{2}{|c|}{ Mean number of unions per strike $=1.58$} \\
\hline
\end{tabular}


Table 5: Strike incidence and the business cycle: annual national unemployment rates, 1920 - 1970

\begin{tabular}{|c|c|c|c|c|c|c|}
\hline & \multicolumn{2}{|c|}{$1920-1970$} & \multicolumn{2}{|c|}{$1920-1938$} & \multicolumn{2}{|c|}{$1946-1970$} \\
\hline & $\mathrm{P}$ & N-P & $\mathrm{P}$ & N-P & $\mathrm{P}$ & N-P \\
\hline $\begin{array}{l}\text { Companies } \\
\text { (see equation (1)) }\end{array}$ & $\begin{array}{l}-0.051^{*} \\
(0.023)\end{array}$ & $\begin{array}{l}-0.024 \\
(0.019)\end{array}$ & $\begin{array}{l}-0.028 \\
(0.019)\end{array}$ & $\begin{array}{l}-0.017 \\
(0.025)\end{array}$ & $\begin{array}{l}-0.094 \\
(0.126)\end{array}$ & $\begin{array}{l}-0.047 \\
(0.105)\end{array}$ \\
\hline
\end{tabular}

Note: * indicates significant at 5\% on two-tail-test. Standard errors in parentheses. 
Table 6 Strike durations and the business cycle, 1920 - 1970

(Annual national unemployment rates)

\begin{tabular}{|c|c|c|c|c|c|c|}
\hline \multirow{3}{*}{$\begin{array}{l}\text { Estimation } \\
\text { Method }\end{array}$} & \multicolumn{2}{|c|}{ All years $(1920-1970)$} & \multicolumn{2}{|c|}{ Pre-war (1920 - 1938) } & \multicolumn{2}{|c|}{ Post-war (1946 - 1970) } \\
\hline & $(1)$ & $(2)$ & (3) & $(4)$ & (5) & $(6)$ \\
\hline & $\mathbf{P}$ & $\mathbf{N}-\mathbf{P}$ & $\mathbf{P}$ & $\mathbf{N}-\mathbf{P}$ & $\mathbf{P}$ & $\mathbf{N}-\mathbf{P}$ \\
\hline $\begin{array}{l}\text { Ordinary Least } \\
\text { Squares }\end{array}$ & $\begin{array}{l}-0.016 \\
(0.019)\end{array}$ & $\begin{array}{l}-0.0001 \\
(0.022)\end{array}$ & $\begin{array}{l}-0.034 \\
(0.021)\end{array}$ & $\begin{array}{c}0.051 \\
(0.028)\end{array}$ & $\begin{array}{l}0.329 * \\
(0.159)\end{array}$ & $\begin{array}{c}0.197 \\
(0.160)\end{array}$ \\
\hline $\begin{array}{l}\text { Union Fixed } \\
\text { Effects }\end{array}$ & $\begin{array}{c}0.043 * * \\
(0.016)\end{array}$ & $\begin{array}{c}0.014 \\
(0.018)\end{array}$ & $\begin{array}{c}0.087 * * \\
(0.014)\end{array}$ & $\begin{array}{c}0.029 \\
(0.028)\end{array}$ & $\begin{array}{c}0.287 \\
(0.165)\end{array}$ & $\begin{array}{c}0.191 \\
(0.140)\end{array}$ \\
\hline $\begin{array}{l}\text { Company Fixed } \\
\text { Effects }\end{array}$ & $\begin{array}{l}-0.034 \\
(0.019)\end{array}$ & $\begin{array}{l}-0.008 \\
(0.012)\end{array}$ & $\begin{array}{l}-0.057 \\
(0.038)\end{array}$ & $\begin{array}{l}-0.013 \\
(0.037)\end{array}$ & $\begin{array}{l}0.299 * \\
(0.125)\end{array}$ & $\begin{array}{c}0.182 \\
(0.123)\end{array}$ \\
\hline $\begin{array}{l}\text { Union and } \\
\text { Company Fixed } \\
\text { Effects }\end{array}$ & $\begin{array}{c}0.035 \\
(0.023)\end{array}$ & $\begin{array}{l}-0.0006 \\
(0.014)\end{array}$ & $\begin{array}{c}0.087 \\
(0.049)\end{array}$ & $\begin{array}{l}-0.078 \\
(0.041)\end{array}$ & $\begin{array}{c}0.234 * * \\
(0.088)\end{array}$ & $\begin{array}{c}0.067 \\
(0.136)\end{array}$ \\
\hline $\begin{array}{l}\text { Sample sizes } \\
\text { (number of } \\
\text { clusters) }\end{array}$ & $\begin{array}{l}5274 \\
(51)\end{array}$ & $\begin{array}{c}5334 \\
(51)\end{array}$ & $\begin{array}{l}360 \\
(19)\end{array}$ & $\begin{array}{l}296 \\
(19)\end{array}$ & $\begin{array}{l}4583 \\
(25)\end{array}$ & $\begin{array}{l}4678 \\
(25)\end{array}$ \\
\hline $\begin{array}{l}\text { Union groups } \\
\text { (company } \\
\text { groups) }\end{array}$ & $\begin{array}{c}119 \\
(1297)\end{array}$ & $\begin{array}{c}107 \\
(1241)\end{array}$ & $\begin{array}{c}56 \\
(274)\end{array}$ & $\begin{array}{c}55 \\
(182)\end{array}$ & $\begin{array}{c}83 \\
(1023)\end{array}$ & $\begin{array}{c}77 \\
(1053)\end{array}$ \\
\hline $\begin{array}{l}\text { Mean duration } \\
\text { (days) }\end{array}$ & 9.2 & 4.8 & 46.3 & 9.5 & 6.6 & 4.5 \\
\hline
\end{tabular}

Notes: Annual unemployment rates taken from Denham and McDonald (1996).All regressions include a quadratic time trend. Robust standard errors allow for clustering by year. ** $\left(^{*}\right)$ denotes two-tail significance at $0.01(0.05)$ level. 
Table 7 Strike durations and the business cycle, 1960-1970

(Monthly district unemployment rates)

\begin{tabular}{|c|c|c|}
\hline \multicolumn{3}{|c|}{ Unemployment coefficients [Dependent Variable: log duration] } \\
\hline & $\mathbf{P}$ & $\mathbf{N}-\mathbf{P}$ \\
\hline \multicolumn{3}{|c|}{ ORDINARY LEAST SQUARES } \\
\hline (a) (year dummies) & $\begin{array}{c}0.046 \\
(0.048)\end{array}$ & $\begin{array}{l}0.065^{*} \\
(0.032)\end{array}$ \\
\hline (b) (quadratic time trend) & $\begin{array}{l}0.089 * \\
(0.045)\end{array}$ & $\begin{array}{c}0.089 * * \\
(0.027)\end{array}$ \\
\hline \multicolumn{3}{|c|}{ UNION FIXED EFFECTS } \\
\hline (a) (year dummies) & $\begin{array}{c}0.044 \\
(0.047)\end{array}$ & $\begin{array}{l}0.068^{*} \\
(0.030)\end{array}$ \\
\hline (b) (quadratic time trend) & $\begin{array}{l}0.082 * \\
(0.040)\end{array}$ & $\begin{array}{c}0.090^{* *} \\
(0.026)\end{array}$ \\
\hline \multicolumn{3}{|c|}{ COMPANY FIXED EFFECTS } \\
\hline (a) (year dummies) & $\begin{array}{c}0.033 \\
(0.048)\end{array}$ & $\begin{array}{c}0.047 \\
(0.027)\end{array}$ \\
\hline (b) (quadratic time trend) & $\begin{array}{c}0.047 \\
(0.039)\end{array}$ & $\begin{array}{l}0.055^{*} \\
(0.023)\end{array}$ \\
\hline \multicolumn{3}{|c|}{ UNION and COMPANY FIXED EFFECTS } \\
\hline (a) (year dummies) & $\begin{array}{c}0.014 \\
(0.054)\end{array}$ & $\begin{array}{c}0.073^{* *} \\
(0.027)\end{array}$ \\
\hline (b) (quadratic time trend) & $\begin{array}{c}0.020 \\
(0.042)\end{array}$ & $\begin{array}{c}0.063 * * \\
(0.024)\end{array}$ \\
\hline Sample sizes (number of clusters) & $3673(987)$ & $3461(942)$ \\
\hline Union groups (company groups) & $69(864)$ & $61(763)$ \\
\hline Mean duration (days) & 6.6 & 4 \\
\hline
\end{tabular}

Notes: The data cover 11 years by 12 months by 54 districts. All regressions include district and month dummies. Robust standard errors allow for clustering at the year/month/district level. ${ }^{* *}(*)$ denotes two-tail significance at $0.01(0.05)$ level. 
Table 8 Successful strike outcomes (from the union standpoint) and the business cycle: pre- and post-war periods (National annual unemployment rates)

\begin{tabular}{|c|c|c|c|c|}
\hline \multirow[t]{3}{*}{ Estimation Method } & \multicolumn{2}{|c|}{ Pre-war (1920 - 1938) } & \multicolumn{2}{|c|}{ Post-war (1946 - 1970) } \\
\hline & (1) & $(2)$ & (3) & (4) \\
\hline & $\mathbf{P}$ & $\mathbf{N}-\mathbf{P}$ & $\mathbf{P}$ & N-P \\
\hline $\begin{array}{l}\text { Ordinary Least } \\
\text { Squares }\end{array}$ & $\begin{array}{c}-0.032^{* *} \\
(0.004)\end{array}$ & $\begin{array}{l}-0.020^{*} \\
(0.009)\end{array}$ & $\begin{array}{l}-0.019 \\
(0.049)\end{array}$ & $\begin{array}{l}-0.080 \\
(0.050)\end{array}$ \\
\hline Union Fixed Effects & $\begin{array}{c}-0.026 * * \\
(0.007)\end{array}$ & $\begin{array}{l}-0.006 \\
(0.007)\end{array}$ & $\begin{array}{l}-0.035 \\
(0.051)\end{array}$ & $\begin{array}{l}-0.067 \\
(0.044)\end{array}$ \\
\hline Company Fixed Effects & $\begin{array}{c}-0.042 * * \\
(0.009)\end{array}$ & $\begin{array}{l}-0.008 \\
(0.006)\end{array}$ & $\begin{array}{l}-0.029 \\
(0.041)\end{array}$ & $\begin{array}{l}-0.051^{*} \\
(0.026)\end{array}$ \\
\hline $\begin{array}{l}\text { Union \& Company } \\
\text { Fixed Effects }\end{array}$ & $\begin{array}{l}-0.028 * \\
(0.013)\end{array}$ & $\begin{array}{c}0.011 \\
(0.012) \\
\end{array}$ & $\begin{array}{l}-0.061 \\
(0.037)\end{array}$ & $\begin{array}{l}-0.062^{*} \\
(0.029) \\
\end{array}$ \\
\hline $\begin{array}{l}\text { Sample sizes (number } \\
\text { of clusters) }\end{array}$ & $\begin{array}{l}360 \\
(19)\end{array}$ & $\begin{array}{l}296 \\
(19)\end{array}$ & $\begin{array}{l}4583 \\
(25)\end{array}$ & $\begin{array}{l}4678 \\
(25)\end{array}$ \\
\hline $\begin{array}{l}\text { Union groups } \\
\text { (company groups) }\end{array}$ & $\begin{array}{c}56 \\
(274)\end{array}$ & $\begin{array}{c}55 \\
(182)\end{array}$ & $\begin{array}{c}83 \\
(1023)\end{array}$ & $\begin{array}{c}77 \\
(1053)\end{array}$ \\
\hline Mean duration (days) & 46.3 & 9.5 & 6.6 & 4.5 \\
\hline
\end{tabular}

Notes: Annual unemployment rates taken from Denham and McDonald (1996).All regressions include a quadratic time trend. Robust standard errors allow for clustering by year. $* *(*)$ denotes two-tail significance at $0.01(0.05)$ level.

Appendix Table 4 gives the breakdown between successful strike outcomes and unsuccessful ones. 
Appendix Table 1: Local Unemployment Districts used in 1960-1970 regressions

\begin{tabular}{|l|l|l|l|}
\hline 1 & Aberdeen & 28 & Leicester \\
\hline 2 & Barrow & 29 & Lincoln \\
\hline 3 & Bedfordshire & 30 & Liverpool \\
\hline 4 & Belfast Marine & 31 & London \\
\hline 5 & Birkenhead & 32 & Manchester \\
\hline 6 & Birmingham & 33 & Mid Anglian \\
\hline 7 & Blackburn & 34 & North East Coast \\
\hline 8 & Bolton & 35 & Northern Ireland \\
\hline 9 & Border Counties & 36 & North Staffordshire \\
\hline 10 & Bradford & 37 & North West Scotland \\
\hline 11 & Burnley & 38 & Northern Counties \\
\hline 12 & Burton & 39 & Nottinghm \\
\hline 13 & Chester & 40 & Oldham \\
\hline 14 & Coventry & 41 & Outer London \\
\hline 15 & Derby & 42 & Peterborough \\
\hline 16 & Dundee & 43 & Preston \\
\hline 17 & East Anglia & 44 & Rochdale \\
\hline 18 & East Midlands & 45 & South Wales \\
\hline 19 & East Scotland & 46 & Scottish \\
\hline 20 & Grimsby & 47 & Sheffield \\
\hline 21 & Halifax & 48 & Shropshire \\
\hline 22 & Huddersfield & 49 & South Eastern \\
\hline 23 & Hull & 50 & St Helens \\
\hline 24 & Keighley & 51 & West of England \\
\hline 25 & Kilmarnock & 53 & Wakefield \\
\hline 26 & Lancashire & West Midlands \\
\hline 27 & Leeds & Wigan \\
\hline
\end{tabular}

Source: Ministry of Labour Gazette (various issues), 'Numbers Unemployed in Principal Towns and Development Areas’, London (HMSO). 
Appendix Table 2 Stoppages of work in the Metal, Engineering and Shipbuilding Industries, 1914-1945

\begin{tabular}{|c|c|c|c|}
\hline Year & Number of strikes* & $\begin{array}{l}\text { Number of workers } \\
\text { directly and indirectly } \\
\text { involved* }(000)\end{array}$ & $\begin{array}{c}\text { Number of working } \\
\text { days lost** } \\
(000)\end{array}$ \\
\hline 1914 & 232 & 51 & 1308 \\
\hline 1915 & 189 & 46 & 357 \\
\hline 1916 & 105 & 75 & 305 \\
\hline 1917 & 225 & 429 & 3063 \\
\hline 1918 & 420 & 242 & 1499 \\
\hline 1919 & 335 & 403 & 12284 \\
\hline 1920 & 340 & 183 & 3414 \\
\hline 1921 & 151 & 63 & 4420 \\
\hline 1922 & 115 & 369 & 17484 \\
\hline 1923 & 103 & 61 & 5997 \\
\hline 1924 & 136 & 71 & 1400 \\
\hline 1925 & 94 & 24 & 184 \\
\hline 1926 & 62 & 14 & 221 \\
\hline 1927 & 69 & 16 & 81 \\
\hline 1928 & 51 & 8 & 60 \\
\hline 1929 & 80 & 39 & 768 \\
\hline 1930 & 70 & 10 & 92 \\
\hline 1931 & 61 & 12 & 99 \\
\hline 1932 & 46 & 4 & 48 \\
\hline 1933 & 68 & 15 & 112 \\
\hline 1934 & 81 & 15 & 160 \\
\hline 1935 & 73 & 17 & 93 \\
\hline 1936 & 148 & 47 & 206 \\
\hline 1937 & 220 & 107 & 778 \\
\hline 1938 & 138 & 44 & 243 \\
\hline 1939 & 181 & 56 & 332 \\
\hline 1940 & 229 & 40 & 163 \\
\hline 1941 & 472 & 154 & 556 \\
\hline 1942 & 476 & 141 & 526 \\
\hline 1943 & 612 & 170 & 635 \\
\hline 1944 & 610 & 194 & 1048 \\
\hline 1945 & 591 & 123 & 528 \\
\hline
\end{tabular}

Source: Knowles (1952, p. 308).

* Relates to strikes beginning in year

** Relates to strikes in progress during year 
Appendix Table 3 Strike frequency by union

\begin{tabular}{|c|c|c|c|c|c|c|c|}
\hline $\begin{array}{l}\text { No. of } \\
\text { Strikes }\end{array}$ & Freq. & Percent & Cum.\% & $\begin{array}{l}\text { No. of } \\
\text { Strikes }\end{array}$ & Freq. & Percent & Cum.\% \\
\hline 1 & 43 & 29.25 & 29.25 & 40 & 1 & 0.68 & 81.63 \\
\hline 2 & 23 & 15.65 & 44.90 & 42 & 1 & 0.68 & 82.31 \\
\hline 3 & 6 & 4.08 & 48.98 & 51 & 1 & 0.68 & 82.99 \\
\hline 4 & 4 & 2.72 & 51.70 & 56 & 1 & 0.68 & 83.67 \\
\hline 5 & 5 & 3.40 & 55.10 & 59 & 1 & 0.68 & 84.35 \\
\hline 6 & 3 & 2.04 & 57.14 & 71 & 1 & 0.68 & 85.03 \\
\hline 7 & 1 & 0.68 & 57.82 & 80 & 1 & 0.68 & 85.71 \\
\hline 8 & 2 & 1.36 & 59.18 & 84 & 2 & 1.36 & 87.07 \\
\hline 9 & 3 & 2.04 & 61.22 & 85 & 1 & 0.68 & 87.76 \\
\hline 10 & 3 & 2.04 & 63.27 & 96 & 1 & 0.68 & 88.44 \\
\hline 11 & 5 & 3.40 & 66.67 & 97 & 1 & 0.68 & 89.12 \\
\hline 12 & 1 & 0.68 & 67.35 & 104 & 2 & 1.36 & 90.48 \\
\hline 13 & 2 & 1.36 & 68.71 & 132 & 1 & 0.68 & 91.16 \\
\hline 14 & 2 & 1.36 & 70.07 & 209 & 1 & 0.68 & 91.84 \\
\hline 16 & 1 & 0.68 & 70.75 & 213 & 1 & 0.68 & 92.52 \\
\hline 17 & 2 & 1.36 & 72.11 & 235 & 1 & 0.68 & 93.20 \\
\hline 19 & 1 & 0.68 & 72.79 & 243 & 1 & 0.68 & 93.88 \\
\hline 20 & 2 & 1.36 & 74.15 & 252 & 1 & 0.68 & 94.56 \\
\hline 23 & 2 & 1.36 & 75.51 & 313 & 1 & 0.68 & 95.24 \\
\hline 24 & 2 & 1.36 & 76.87 & 390 & 1 & 0.68 & 95.92 \\
\hline 25 & 1 & 0.68 & 77.55 & 416 & 1 & 0.68 & 96.60 \\
\hline 28 & 1 & 0.68 & 78.23 & 824 & 1 & 0.68 & 97.28 \\
\hline 30 & 1 & 0.68 & 78.91 & 1107 & 1 & 0.68 & 97.96 \\
\hline 31 & 1 & 0.68 & 79.59 & 1198 & 1 & 0.68 & 98.64 \\
\hline 33 & 1 & 0.68 & 80.27 & 1482 & 1 & 0.68 & 99.32 \\
\hline \multirow[t]{2}{*}{39} & 1 & 0.68 & 80.95 & 1785 & 1 & 0.68 & 100.00 \\
\hline & & & & Total & 147 & & \\
\hline
\end{tabular}




\section{Appendix Table 4}

\section{Classification of strike outcomes}

\begin{tabular}{ll}
\hline Unsuccessful & Successful \\
\hline Work resumed unconditionally & Discussions/Investigations opened \\
Work resumed. Discussions resumed. & Matter resolved pending discussions \\
Strike continued into following year & Partial concessions made \\
Workers dismissed & Full demands met \\
Workers voluntarily left company & Work resumed \\
Miscellaneous & Miscellaneous \\
\hline
\end{tabular}

